\title{
UDC 338.48:65.011
}

\section{Tsviliy Sergiy}

tsviliy@i.ua,ORCID ID: 0000-0002-1720-6238, ResearcherID: AAG-6759-2020

Ph.D., Associate Professor,

Associate Professor at the Department of Tourism, Hotel and Restaurant Business,

National University "Zaporizhzhia Polytechnic», Zaporizhzhia

\section{Vasylychev Denys}

vasilichev@ukr.net, ORCID ID:0000-0002-5057-7575

Ph.D., Associate Professor,

Associate Professor at the Department of Economy and Customs,

National University «Zaporizhzhia Polytechnic», Zaporizhzhia

\section{Halan Olena}

halan_o@gmail.com, ORCID ID:0000-0001-6061-5224

Ph.D., Associate Professor,

Associate Professor at the Department of Economy and Customs,

National University "Zaporizhzhia Polytechnic», Zaporizhzhia

\section{POSTCORONAVIRUS TRANSFORMATION OF ECONOMIC SECURITY OF MICRO-ENTERPRISES OF THE REGIONAL SPHERE OF TOURISM}

\begin{abstract}
The article examines the scientific experience in developing optimal steps in the postcoronavirus period of development of the domestic tourist region to a systematic vision of a comprehensive strategy taking into account the interests of firms. The theoretical basis for the essence of the concept of "safety in tourism" is studied and the own vision of its modern content is offered. It is established that in the post-coronavirus perspective of the tourism industry there is a need to review approaches to the formation and provision of economic security in order to maintain a stable position of enterprises in domestic and international markets, both in real and digital environment. It is determined that the structure of economic security of the tourist sphere of the region will have the following components: ecological, financial, investment, social, innovative, functional; the composition of the system of economic security of the tourist micro-enterprise is logically expressed by the components: tourist, technical and economic; financial, personnel, information. The tasks of economic security of the tourist enterprise of the region in the postcoronavirus era of business transformation are offered. It is concluded that the concept of creating a mechanism of economic security in the regional sphere of tourism provides a harmonious system of combining the priority interests of the enterprise and the environment. The basic stages of the methodology of development of the system of economic security of the microenterprise of the regional sphere of tourism in the postcoronavirus business space are formed. It is one of the priority areas for strengthening the economic security of tourism micro-entrepreneurship in the region: policy tools at the macro-level hierarchy of economic management and policy tools at the mesolevel hierarchy of economic management. The structure of management functions of local authorities in the direction of forming a safe environment for tourism is shown schematically. The main requirements defined by the concept of economic security of the micro-business sector in tourism in the region are presented.
\end{abstract}

Key words: microbusiness, tourism, economic security, entrepreneurship, region.

JEL Classification: L83, M21, Z32

DOI: https://doi.org/10.36477/2522-1256-2021-30-10

\section{Цвілий С. М.}

tsviliy@i.ua,ORCID ID: 0000-0002-1720-6238, ResearcherID: AAG-6759-2020

к.е.н., доцент, доцент кафедри туристичного, готельного та ресторанного бізнесу, Національний університет «Запорізька політехніка», м. Запоріжжя

\section{Василичев Д. В.}

vasilichev@ukr.net, ORCID ID:0000-0002-5057-7575

к.е.н., доцент, доцент кафедри економіки та митної справи,

Національний університет «Запорізька політехніка», м. Запоріжжя 
Галан О.

halan_o@gmail.com, ORCID ID:0000-0001-6061-5224

к.е.н., дочент, доцент кафедри економіки та митної справи,

Національний університет «Запорізька політехніка», м. Запоріжжя

\title{
ПОСТКОРОНАВІРУСНА ТРАНСФОРМАЦІЯ ЕКОНОМІЧНОЇ БЕЗПЕКИ МІКРОПІДПРИЕМСТВ РЕГІОНАЛЬНОЇ СФЕРИ ТУРИЗМУ
}

\begin{abstract}
Анотація. У статті досліджено науковий досвід розробки оптимальних кроків до систематичного бачення комплексної стратегї з урахуванням інтересів фірм у посткоронавірусний період розвитку вітчизняного туристичного регіону. Досліджено теоретичну основу сутності поняття "безпека в туризмі" та запропоновано власне бачення його сучасного змісту. Встановлено, шо у перспективі розвитку туристичної галузі після коронавірусу існує необхідність переглянути підходи до формування та забезпечення економічної безпеки з метою підтримання стабільного стану підприємств на внутрішньому та міжнародному ринках як у реальному, так й у иифровому середовищі. Визначено, що структура економічної безпеки регіональної туристичної сфери матиме такі складові: екологічну, фінансову, інвестиційну, соціальну, інноваційну, функціональну; склад системи економічної безпеки туристичного мікропідприємства логічно виражається компонентами: туристичний, технічний та економічний, фінансовий, кадровий, інформаційний. Сформульовано завдання економічної безпеки туристичного підприємства регіону у посткоронавірусний період трансформації бізнесу. Зроблено висновок, щзо концепція створення механізму економічної безпеки в регіональній сфері туризму передбачає гармонійну систему поєднання пріоритетних інтересів підприємства та навколишнього середовища. Сформовано основні етапи методологї розвитку системи економічної безпеки мікропідприємства регіональної сфери туризму у посткоронавірусному діловому просторі. Це один з пріоритетних напрямів посилення економічної безпеки туристичного мікропідприємництва у регіоні: інструменти політики на макрорівневій ієрархї економічного управління та інструменти політики на ієрархії економічного управління на мезорівні. Схематично показано структуру управлінських функиій місиевої влади у напрямку формування безпечного середовища для туризму. Представлені основні вимоги до визначення концепції економічної безпеки сектору мікробізнесу в туризмі регіону.
\end{abstract}

Ключові слова: мікробізнес, туризм, економічна безпека, підприємництво, регіон.

Formulation of the problem. The transformation of the regional economy to the post-coronavirus era is accompanied by the emergence of management problems that are extremely complex in content, their solution must be found by combining the efforts of leading scientific schools using the results of retrospective analysis of economic tourism systems in the conditions of COVID-19, both nationally and internationally [1]. It should be assumed that the creation of a new paradigm of regional tourism economy is becoming an additional factor in its globalization. The search for a vision of development during and after the COVID-19 pandemic is gradually transforming the region's tourism sector into an effective mechanism for developing optimal steps towards a systematic vision of a comprehensive strategy, taking into account the interests of firms. However, micro-enterprises in the region often find themselves at a disadvantage in the market, as largescale competitors have much stronger capital, an attractive brand and strong leverage. The operators of the regional market have an additional organizational, legal and economic burden [8]. From this point of view, the traditional approach to the use of classical tools to combat competitors is ineffective and requires immediate review, as well as the entire management system of the micro-enterprise on the specifics of the business. Therefore, it is necessary to approach the formation of post-coronavirus business space in the regional sphere of tourism on the basis of economic security.

Analysis of recent research and publications. Significant experience of scientific research on economic security has been accumulated in foreign and domestic science and practice, among which the works of D. Lambert, V. Yarochkin, V. McMack, Z. Varnalii, T. Vasyltsiv, V. Muntian, M. Bendikova, G. Pasternak-Taranushchenko should be noted. Among the authors who consider the principles of economic security, the formation of mechanisms for ensuring, assessing the economic security of the enterprise should be distinguished works: M. Barna, N. Vashchenko, S. Glushchenko, O. Vlasyuk, L. Donets, N. Kapustina, T. Kovaleva, G. Kozachenko, L. Korchevska, M. Kurkina, O. Lyashenko, E. Oleynikov, O. Razdin, V. Tambovtsev, L. Shemayev, V. Shlykov. The achievements of such well-known specialists as L. Batchenko, I. Zinoviev, 
I. Melnyk, V. Kvartalny, V. Kozyrev, M. Marinin, H. Savina, A. Taksanov, L. Tranchenko, S. Tsokhly, O. Chudnovsky are devoted to the problems of economic security management in the field of tourism. Some aspects related to the functioning and development of the world tourism industry are covered in the works of such foreign scholars as R. Barton, P. Bernecker, A. Bull, J. Ingram, C. Robinson, G. Harris, J. Holloway. Despite the significant amount of research on this issue, the intensive changes in tourism caused by the factors of COVID-19, lead to the development of a comprehensive vision of postcoronavirus development in this area and the need to improve the management of economic security of microenterprises.

Setting objectives. The aim of the article is to develop directions for the formation of a safe environment for tourism activities based on the study of the prerequisites for postcoronavirus transformation of the economic security of the microcompany.

Presentation of the main research material. Modern economic literature has an arsenal of methods and techniques for studying the economic security of micro-entrepreneurship in the region. However, given the complexity of this economic category, its dependence on economic, social, political, historical, technological, religious, psychological, other factors of society, the purpose, objectives, principles and indicators of tourism micro-entrepreneurship in the region depend on the existing system of government and are based on methodological approaches, methods, evaluation methodology that is acceptable for its evaluation. In any case, the micro-company must fully and effectively use theoretical and methodological approaches to ensure economic security in forming its own position in the postcoronavirus business space of the regional tourism sector in order to quickly restore business activity. Researchers from the Department of Tourism, Hotel and Restaurant Business and the Department of Economy and Customs of the National University
"Zaporizhzhia Polytechnic" (leading Institute of the region) in the work "Tourism industry of Ukraine in the period of European integration: theoretical aspect" explored the concept of "safety in tourism" modern content (Table 1).

According to table 1 concluded that within the concept of "safety in tourism" should distinguish between the safety of tourists, the safety of tourism entities and the state, the safety of the environment. Each of these concepts is multifaceted and requires specific analysis and understanding. In a general sense, the category of "security" can be interpreted as a state of protection of vital interests of all security objects from real or potential, different in origin, external and internal dangers: political, economic, information, environmental, military $[10 ; 11]$. According to the authors, the economic security of a tourism enterprise is a state of protection of the company's activities in the field of tourism from the negative effects of external and internal environment, as well as its ability to quickly eliminate various threats. The content of this concept includes a comprehensive system of means of ensuring sustainable competitiveness and economic stability of the tourism enterprise, and the main purpose of its economic security system is to ensure sustainable and effective development for the realization of tourism potential in the post-coronavirus business space. It is worth noting that in the post-coronavirus period of tourism there is a need to review approaches to the formation and provision of economic security in order to maintain a stable position of enterprises in domestic and international markets, both in real and digital environment [9]. Based on this, the structure of economic security of the tourism sector of the region will have the following components: environmental, financial, investment, social, innovation, as well as functional components. In turn, the composition of the system of economic security of the tourist micro-enterprise is logically expressed by the components: tourist, technical and economic;

Definition of "security in tourism"

Table 1

\begin{tabular}{|l|l|}
\hline \multicolumn{1}{|c|}{ Authors } & \multicolumn{1}{c|}{ Contents of the concept of "safety in tourism" } \\
\hline Zaitseva V. & $\begin{array}{l}\text { A system of comprehensive measures that provide an adequate mechanism to protect the individual } \\
\text { from trouble and conflict during travel. }\end{array}$ \\
\hline Vindyk A. & $\begin{array}{l}\text { Physical and social security should be taken into account by the tourism industry, whose task is to } \\
\text { minimize and prevent threats. }\end{array}$ \\
\hline Tsviliy S. & $\begin{array}{l}\text { Covers the personal and private safety of tourists, the preservation of their property and care for } \\
\text { the environment when traveling. }\end{array}$ \\
\hline Vasylychev D. & $\begin{array}{l}\text { A complex and multifaceted concept that cannot be limited to the protection of tourist facilities } \\
\text { and private security of tourists, but should be considered on many levels: from national security to } \\
\text { security of accommodation, transport, hotel, recreational complexes, tourism centers. }\end{array}$ \\
\hline Halan O. & $\begin{array}{l}\text { With the formation of tourism, the problem of travel safety is exacerbated, and since the participants } \\
\text { of the trips face the corresponding risks, it is necessary to provide the measures to reduce the level } \\
\text { of danger to tourists. }\end{array}$ \\
\hline
\end{tabular}


financial, personnel, information [6]. The success of the enterprise in the conditions of transformation will depend on the constant monitoring of its positions, research of the strengths and weaknesses of its own business and competitors, the ability to adapt to the changing regional business space. Thus, the concept of "safety in tourism" includes: safety of tourists; safety of tourism entities and the state; safety of the environment [2-4].

At the present stage of development of the tourism economy of the regions, a large number of domestic micro-enterprises are in crisis and that is why the management faces the urgent task of forming an effective strategy for economic security of microcompanies in this area to counter external and internal threats, protect economic interests, ensuring the economic security of the micro-company in this area in order to counter external and internal threats, protect the economic interests of the enterprise, ensure stable development, increase efficiency. Depending on the size and production capacity of the enterprise, the availability of resources, scale and specifics of the problems to be solved, different approaches should be used to form a strategy to ensure its economic security. In recent years, domestic tourism companies are creating special units in the structure, the main task of which is to ensure economic security. However, most of these units do not have an effectively functioning system of economic security and this aspect significantly reduces the efficiency of their business and necessitates the development of this strategy. At the same time, the creation of such units is a positive vector for the development of modern microenterprises in the region and shows the understanding of market participants of the main tasks of economic security of the travel company (Fig. 1).
The method of forming the system of economic security of a micro-enterprise in the regional sphere of tourism in the post-coronavirus business space includes the following stages: studying the specifics of the micro-enterprise's business, its market segment, staffing, staff, etc. (1); analysis of external and internal threats to the economic security of the enterprise and the study of information about crisis situations, causes and ways of settlement (2); audit of available security tools, as well as analysis of their compliance with the identified threats (3); modeling of the company's post-coronavirus economic security system (4); development of a plan to eliminate the shortcomings identified during the audit (5); preparation of proposals for improving the economic security system (including the creation of a security service at the enterprise, if such did not exist, or a security system based on it, defining mechanisms for its provision and development of organizational structure of system management) and calculation of all necessary resources (6); planning of monthly expenses for ensuring the functioning of the system of economic security of the tourist micro-firm (7); approval by the management of the model of the modernized system of economic security and the budget for its maintenance (8); organizational procedures for the formation of a new system of economic security (9); evaluation of the efficiency of the formed system and vectors of its improvement (10). The given technique of formation of system of economic safety of the tourist micro-enterprise provides realization of constant control (during and after realization of each stage), adjustment and improvement of directions of formation of system of safety for the purpose of optimum adaptation and reaction to changes in external and internal

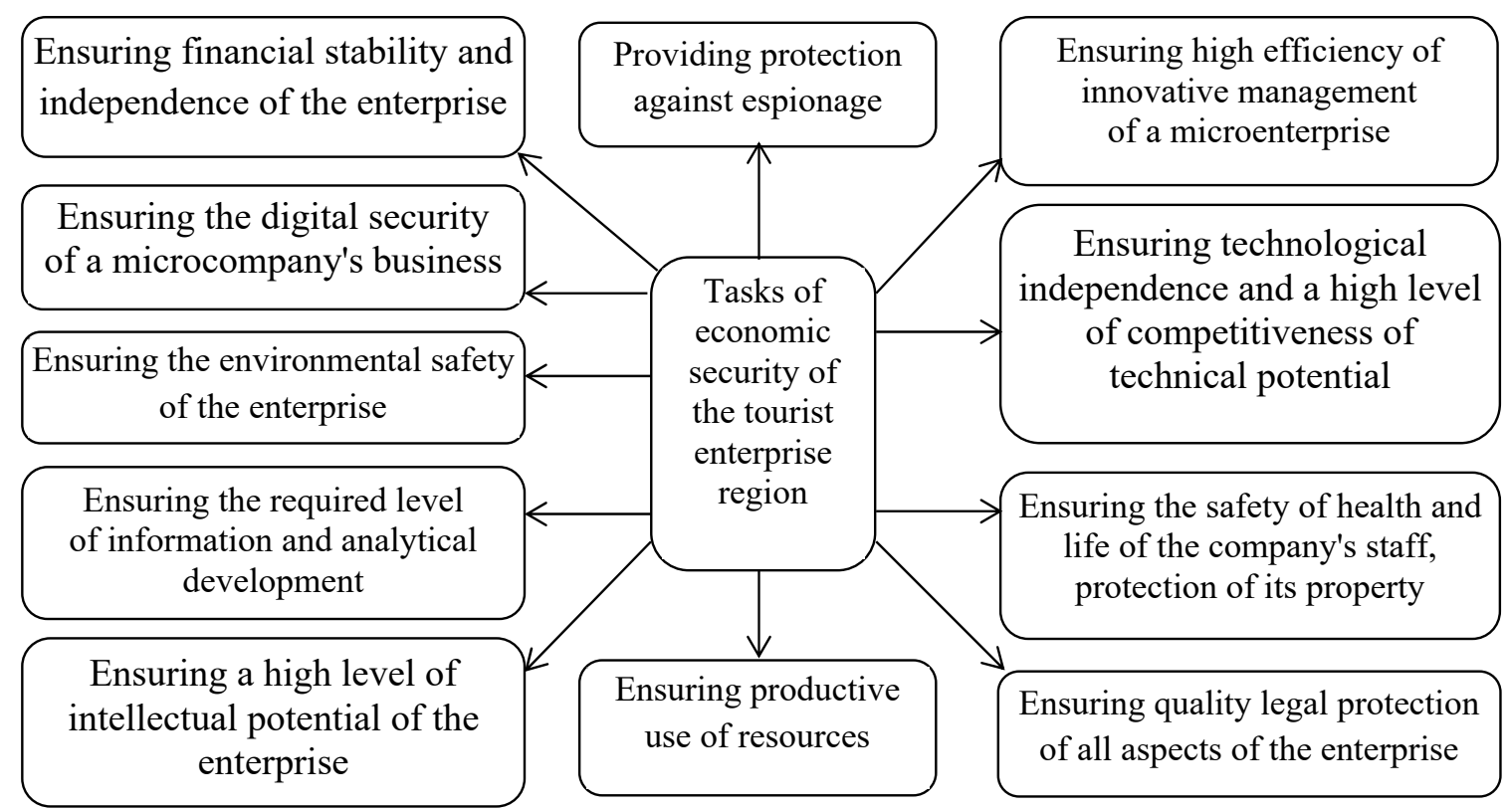

Figure 1. Problems of economic security of the tourist enterprise of the region 
environments, the nature of risks and threats, changes in the legal field, the appearance on the market of unfair competitors, changes in the forms and methods of illegal activities, lists of confidential information and other factors. At the same time, all approaches to the development of technology for assessing the economic security of a micro-enterprise are divided into three groups: a combination of well-known proven techniques (1); independent method of assessing economic security with miscalculations of its functional components (2); comprehensive assessment of the levels of key indicators of business functioning and their ranks (3).

Given the limited budget of domestic microcompanies in the regions and the unpreparedness of a significant number of them to restructure the organizational structure, a slightly different approach to economic security can be used, the essence of which is the maximum delegation of economic security to existing units. In this case, it will not be necessary to radically reform the organizational structure, but will only need to create the position of "director of security" with the authority to lead the process of economic security of the tourist micro-enterprise. This way of solving the problem will ensure an appropriate level of economic security with minimal costs for reforming the organizational structure. However, it should be emphasized that this approach is appropriate only for innovative micro-enterprises, as it has been tested against large and medium-sized tourism companies and requires some adaptation. It is clear that the most significant influence on the activities of micro-enterprises is exerted by the state. However, a retrospective study of the areas of state regulation of micro-business in the region showed that it aims to pursue certain interests that do not always coincide with the interests of enterprises. Due to the discrepancy between state interests and the interests of enterprises in a number of cases, state regulation has a negative impact on the economic security of the enterprise. Under these conditions, tourism microenterprises should intensify efforts to develop a postcoronavirus mechanism for economic security, which the authors propose to understand a set of managerial, economic, organizational, legal, motivational ways to harmonize the interests of the firm with the interests of the environment. The specific of the micro-company in the field of tourism business ensures a sufficient level of profit, the amount of which will be justified for the company to be in economic security [5]. As a result, the concept of creating a mechanism of economic security of a micro-business in tourism should provide that the basis of the mechanism is the formation of a system of priority interests of the enterprise with their subsequent harmonization with the interests of the environment interacting with the micro-firm.

There is also an interdependence between strengthening the economic security of the tourism microenterprise sectors of certain regions of Ukraine and ensuring the national security of the state, including its components such as financial, social, innovation and technological, food, foreign economic, demographic, energy, environmental security, digital. In turn, the development of micro-entrepreneurship is a necessary prerequisite for socio-economic growth, democratization of society, increasing the level of digital transformation, ensuring the European vector of territorial development, modernization of infrastructure of locations, cities, districts, etc. Priority areas for strengthening the economic security of tourism micro-entrepreneurship in the region should include: policy tools at the macro-level of the economic management hierarchy (1), and policy tools at the meso-level of the economic management hierarchy (2). In turn, it is expedient to include in the means of policy at the macro-level the hierarchy of economic management: first, strengthening of program-normative regulation of economic security of tourist activity of micro-enterprises; secondly, promoting the level of motivation of local governments to implement measures to strengthen the economic security of tourism. By means of policy at the meso-level hierarchy of management it makes sense to understand the activation of management functions of local authorities in the direction of creating a safe environment for tourism in a particular region. The structure of these management functions is presented in detail in Fig. 2.

When developing a strategy and a policy, according to the authors, it is necessary to identify a range of factors of negative impact, which will be addressed by the developed measures. In addition to the negative impact of COVID-19 factors, as well as existing preconditions and factors in the regions of Ukraine that hinder the development of micro-entrepreneurship and hinder market-reform transformations and postcoronavirus transformations, significant deterrents are also: credit system, tax policy, lack of favorable investment and investment climate. At the same time, the subjects of the tourism sector of microentrepreneurship do not have the opportunity in the regions to attract available financial and credit resources for entrepreneurial business for investment, innovation, modernization of production facilities. It remains a problem for the micro-enterprises of the region the home system of taxation that reduces business activity of population substantially, stipulates negative attitude of business-environment toward public government bodies. That is, the complex nature of these influences leads to the fact that the financial system of the country, which is a significant investment resource, prefers the speculative nature of circulation in the financial sector (capital accumulation), which almost does not pass into the real (production) sphere of the because the "last" level of profitability is much lower, and the payback period is longer. 
Based on the study of scientific opinions and experience of public authority in tourist regions and the function of regulating the development of entrepreneurship, the requirements are presented, which, according to the authors, are determined by the concept of economic security of microentrepreneurship in tourism (Fig. 3).

From this point of view, the orientation of the system of public regulation of tourism in the regional sector of micro-entrepreneurship to ensure its economic security implies that management decisions made in any area of public regulation of the economy and have an impact on micro-entrepreneurship must be considered and evaluated in terms of their impact on the economic security of the micro-enterprise sector, both during the effects of the COVID-19 pandemic and in the post-coronavirus perspective. The strategic orientation in the management of economic security of the tourist micro-enterprise of the region on longterm and rational sustainable development obliges public administration to make management decisions taking into account not only the set of external and

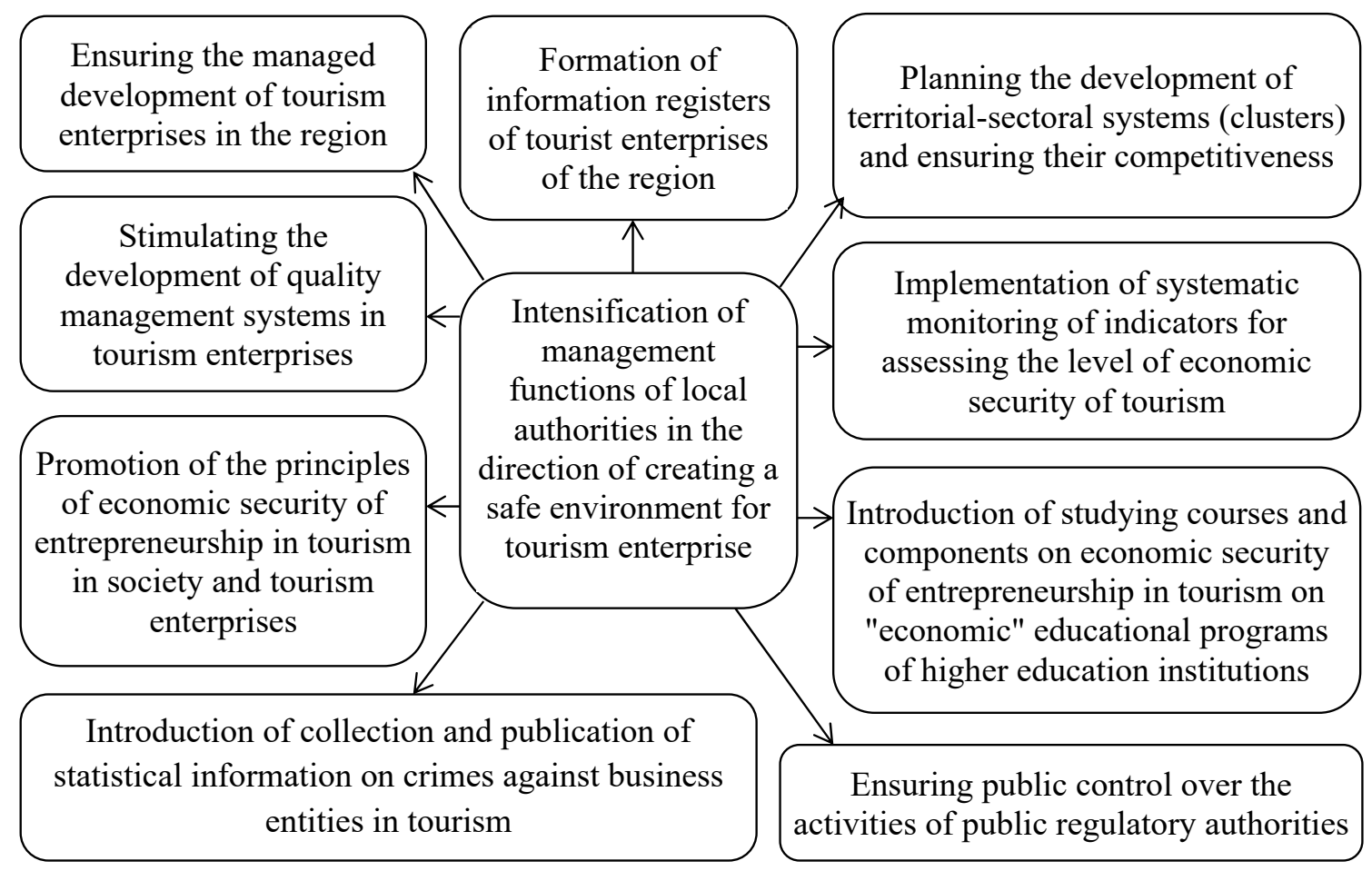

Figure 2. Activation of management functions of local authorities in the direction of creating a safe environment for tourism (structure)

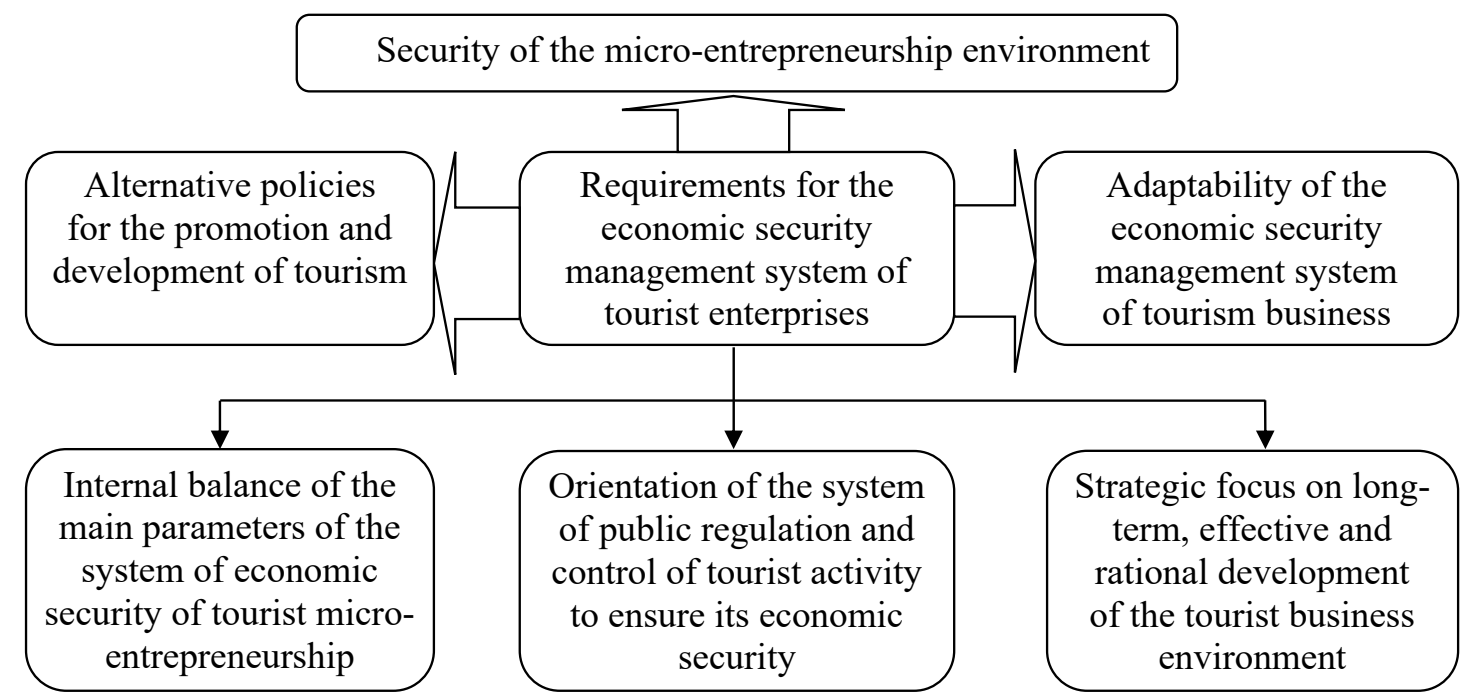

Figure 3. Requirements for effective public policy in ensuring the economic security of tourism micro-enterprises 
internal business environment, but also measures to protect the interests of tourism [7]. Under the conditions of realization of target complex programs of economic safety of tourist microenterprises of the region it is possible to reduce risks and a threshold of their economic safety by means of external factors: target projects.

Conclusions and prospects for further research in this area. In general, strategic preparation for post-coronavirus economic conditions at the level of a domestic tourist region requires procedures for developing a comprehensive balanced system of administrative, socio-economic, legal and managerial nature, which aims to create conditions for the development of a qualitatively new level of tourism potential and ensure the formation of sustainable competitive advantages of tourism micro-entrepreneurship in a particular area while ensuring stable diversified employment and opportunities to participate in projects by business structures. Further scientific interest is required to investigate the activation of tourism micro-business forces in the region in the direction of full-cycle digitalization of processes through the use of the leading experience of companies.

\section{REFERENCES}

1. Gurova, D. D. (2019), "The modern economic impact of tourism" [Suchasnyy ekonomichnyy vplyv turyzmu]. Priazovsky ekonomichnyi visnyk-Priazovsky economic bulletin, № 6 (17), s. 3-7.

2. Durovych A. P. (2003), "Marketing $v$ turizme: uchebnoe posobie" [Marketing in tourism: a textbook]. Novoe znanie, Minsk.

3. Halasyuk, S., and Nezdoyminov. S. (2019), "Orhanizatsiya hotel'noho hospodarstva" [Organization of the hotel industry]. FOP Hulyayeva V.M., Kyiv, Ukraine.
4. Kyfiak, V. (2010), "Stratehiia rozvytku terytorialnykh rekreatsiinykh system: teoriia, metodolohiia, praktyka: monoh." [Strategy of development of territorial recreational systems: theory, methodology, practice: monog], Cher-tsi: XXI, Kyiv, Ukraine.

5. Mochernyi, S. V. (2006), "Internatsionalizatsiia vyrobnytstva i suchasni tendentsii rozvytku svitovoho hospodarstva" [Internationalization of production and modern trends in the world economy]. Ekonomika Ukrainy, № 5, s. 47-55.

6. Strashynska, L. V. (2011), "Marketynh hotelnoho i restorannoho hospodarstva" [Marketing of hotel and restaurant economy]. NUKHT, Kyiv, Ukraine.

7. Stratehiya rozvytku turyzmu Zaporiz'koyi oblasti na 2021-2027 roky [Tourism development strategy of Zaporizhzhia region for 2021-2027], available at: http://www.berda.gov.ua/files/admin/Tourism_development strategy Zp.pdf

8. Varnalij, Z. S. and Xmelevska, L. P. (2017), "Osoblyvosti ta perspektyvy rozvytku ekonomiky znan v Ukrayini" [Features and prospects of knowledge economy development in Ukraine]. Visnyk Kyyivskogo nacionalnogo universytetu texnologij ta dyzajnu. Seriya : Ekonomichni nauky, № 2, S. 7-14.

9. Vasyl'tsiv, T. V. and Shekhlovych, A. (2017), "Finansovo-ekonomichni instrumenty stymuliuvannia rozvytku IT-sfery Ukrainy", Ekonomichnyj dyskurs, № 4, s. 128-136.

10. Zaitseva, V. M. (Eds.) (2021), “Turystychna haluz' Ukrayiny v period Yevro-intehratsiyi: teoretychnyy aspekt" [Tourist branch of Ukraine in the period of Eurointegration: theoretical aspect], NU "ZP", Zaporizhzhia, Ukraine.

11. Zaitseva, V. and Filei, Y. (2010), "Pravove rehulyuvannya turystychnoyi diyal'nosti: navch. pos." [Legal regulation of tourism], Prosvita, Zaporizhzhia, Ukraine.

Стаття надійшла до редакиії 17 червня 2021 р. 